\title{
Evaluation of Seed Transmission of Turnip yellow mosaic virus and Tobacco mosaic virus in Arabidopsis thaliana
}

\author{
F. M. de Assis Filho and J. L. Sherwood
}

Department of Plant Pathology, The University of Georgia, Athens 30602.

Accepted for publication 18 July 2000.

\begin{abstract}
de Assis Filho, F. M., and Sherwood, J. L. 2000. Evaluation of seed transmission of Turnip yellow mosaic virus and Tobacco mosaic virus in Arabidopsis thaliana. Phytopathology 90:1233-1238.

The mechanism of virus transmission through seed was studied in Arabidopsis thaliana infected with Turnip yellow mosaic virus (TYMV) and Tobacco mosaic virus (TMV). Serological and biological tests were conducted to identify the route by which the viruses reach the seed and subsequently are located in the seed. Both TYMV and TMV were detected in seed from infected plants, however only TYMV was seedtransmitted. This is the first report of transmission of TYMV in seed of A. thaliana. Estimating virus seed transmission by grow-out tests was
\end{abstract}

ABSTRACT more accurate than enzyme-linked immunosorbent assay due to the higher frequency of antigen in the seed coat than in the embryo. Virus in the seed coat did not lead to seedling infection. Thus, embryo invasion is necessary for seed transmission of TYMV in A. thaliana. Crosses between healthy and virus-infected plants indicated that TYMV from either the female or the male parent could invade the seed. Conversely, invasion from maternal tissue was the only route for TMV to invade the seed. Pollination of flowers on healthy A. thaliana with pollen from TYMVinfected plants did not result in systemic infection of healthy plants, despite TYMV being carried by pollen to the seed.

Additional keyword: gamete transmission.
The presence of virus in a seed (37), even in the embryo (24, $32,44)$, does not always lead to seedling infection. This property distinguishes a seedborne virus that is carried by the seed but does not infect the seedling from a seed-transmitted virus that does infect the seedling produced from the seed (31). Virus may invade any seed part (2), but seed transmission most frequently results from embryo infection (29). Embryo invasion depends on virus invasion of the floral meristem and subsequent establishment in the gametophytes and gametes $(5,10)$.

Methods such as enzyme-linked immunosorbent assay (ELISA) and polymerase chain reaction (PCR) to index seed for virus either overestimate or underestimate the amount of transmission (28). ELISA commonly has been used for evaluation of virus incidence in seed (28), but this method does not distinguish seedborne from seed-transmitted virus and thereby may overestimate the amount of transmission. Although grow-out tests have been more accurate than ELISA in estimating seed transmission $(17,41,47)$, there are reports of complete correlation between serology and grow-out tests $(6,15)$, particularly when the virus is absent from the seed coat or when only embryos are tested.

Arabidopsis thaliana L. Heynh. is a useful host to study hostpathogen interactions. A. thaliana was chosen as a host to investigate seed transmission with Turnip yellow mosaic virus (TYMV) and Tobacco mosaic virus (TMV) because of the short life cycle of $A$. thaliana and its capacity to produce a large number of seed. In addition, both TYMV and TMV reach a high concentration in tissue of infected $A$. thaliana.

This paper reports the use of serological and biological assays to identify the route by which TYMV and TMV reach the seed of A. thaliana and the association between embryo infection and

Corresponding author: J. L. Sherwood; E-mail address: sherwood@arches.uga.edu

Publication no. P-2000-0825-01R

(C) 2000 The American Phytopathological Society subsequent seed transmission. To our knowledge, this is the first report of TYMV seed transmission in A. thaliana.

\section{MATERIALS AND METHODS}

Plant material and viruses. Seeds of $A$. thaliana ecotypes Dijon and La-O (Arabidopsis Biological Resource Center, Ohio State University) were sown in disposable plastic pots $(7.5 \times 5.5 \times$ $6.0 \mathrm{~cm}$ ) containing autoclaved potting mixture. The seedlings were grown at $23^{\circ} \mathrm{C}$ under $16 \mathrm{~h}$ light, $8 \mathrm{~h}$ dark cycles. An isolate of TYMV maintained on Chinese cabbage (Brassica pekinensis Rubr.) and the common strain of $\operatorname{TMV}(36,38)$ maintained on Nicotiana tabacum L., stored as dehydrated tissue at $4^{\circ} \mathrm{C}$, were used in this study. Inocula was prepared by grinding infected tissue in phosphate buffer $(0.01 \mathrm{M}, \mathrm{pH} 7.0)$ and was applied on corundum-dusted leaves of $A$. thaliana at the rosette stage by a cotton swab. For coinfection of A. thaliana with TYMV and TMV, plants were first inoculated with TYMV and after 10 min leaves other than those previously inoculated received the TMV inoculum. Healthy control plants were kept separate from infected plants. Mature seed were harvested, air dried, and stored at $4^{\circ} \mathrm{C}$.

Virus distribution in infected plants. TYMV and TMV distribution in infected plants were investigated by infectivity and protein A sandwich enzyme-linked immunosorbent assays (PASELISA) (14) on samples of: (i) blossoms; (ii) fully developed flowers dissected into sepals, petals, gynoecium, and stamens; (iii) siliques (seeds included) at the earliest stage of development; (iv) immature siliques divided into shell and seeds; (v) mature siliques divided into shells and seeds; (vi) root; and (vii) stem. Flowers and siliques were dissected under a stereoscopic microscope with fine tip forceps that were cleaned with trisodium phosphate $\left(\mathrm{Na}_{3} \mathrm{PO}_{4} ; 10 \%\right.$, wt/vol $)$ after handling each organ. Infectivity tests were carried out by mechanical inoculation onto Chinese cabbage and N. tabacum 'Xanthi', which are hosts for TYMV and TMV, respectively $(27,48)$. Inocula was prepared by macerating a group of each organ $(\approx 10$ blossoms, parts from 40 flowers, 20 earliest 
siliques, and 10 immature or mature siliques) in $\approx 100 \mu \mathrm{l}$ of phosphate buffer $(0.01 \mathrm{M}, \mathrm{pH} 7.0)$ in a 12 -well porcelain plate with a disposable culture tube.

The procedure for PAS-ELISA was a modification of that of Edwards and Cooper (14). Polyclonal antisera specific for TYMV and TMV were produced as previously described (36). Protein A (Sigma Chemical Co., St. Louis) in carbonate buffer ( $\mathrm{pH} \mathrm{9.6),}$ protein A alkaline phosphatase conjugate (Sigma) in phosphate buffered-saline with Tween (PBST) at $1 \mu \mathrm{g} / \mathrm{ml}$, and $p$-nitrophenyl phosphate (Sigma) at $1 \mathrm{mg} / \mathrm{ml}$ in $1 \mathrm{M}$ diethanolamine ( $\mathrm{pH} 9.8$ ) were used. The assay was carried out in polystyrene plates (NuncImmuno Plate MaxSorp Surface, Roskilde, Denmark) with $100 \mu \mathrm{l}$ per well for each reagent. The incubations were at $37^{\circ} \mathrm{C}$, except for the sample incubation that was at $4^{\circ} \mathrm{C}$. Samples were macerated in a 12-well porcelain plate with a disposable culture tube in $300 \mu \mathrm{l}$ of PBST containing ( $2 \%$, wt/vol) polyvinylpyrrolidone with a molecular weight of 40,000 ( $\mathrm{pH} 7.4)$. Each sample was assayed in triplicate, and assays were repeated with different samples at least four times. The absorbance was read at $405 \mathrm{~nm}$ (EIA Reader EL-307, Bio-Tek Instruments Inc., Burlington, VT) with a healthy sample as a blank. The negative threshold for both TYMV and TMV was $\bar{X} \pm 3$ SD $(11,42)$ of the six wells of healthy control samples. The ELISA procedure was the same throughout unless otherwise indicated.

Effect of virus infection on seed germination. The effect of TYMV and TMV infection on seed germination was evaluated by placing seeds on water-dampened filter paper in a petri dish under ambient light at room temperature and counting the number of seed that germinated after 10, 15, 20, 25, 30, and 40 days. The number of seeds evaluated in each treatment per experiment ranged from 186 to 283 . The ungerminated seeds were counted and assayed for virus by PAS-ELISA. A seed was considered to have germinated if cotyledons, hypocotyl, and primary root were observed.

Evaluation of two methods for determining seed transmission of TYMV and TMV in A. thaliana. Seeds collected from TYMV- or TMV-infected plants were tested for virus by grow-out tests and PAS-ELISA. Grow-out tests were carried out by sowing seed from infected plants in disposable plastic pots, and seedlings were grown as described. Extracts of leaves, flowers, and siliques were assayed by PAS-ELISA. Extract from each tissue were tested in triplicate, and each test was repeated three times. For ELISA on the whole seed, a total of 274 seeds were individually assayed by PAS-ELISA for TYMV, whereas for TMV six groups of 20 seeds and six groups of 10 seeds were used. Results from the grow-out tests and PAS-ELISA of whole seed were compared to estimate seed transmission. Seed from virus infected plants were evaluated through successive generations by grow-out tests to determine seed transmission over the generations. Twelve seedlings of ecotypes Dijon and La-O were mechanically inoculated with either TMV or TYMV to produce seed (named $\mathrm{SV}_{0}$ ). Subsequently, the number of parent plants for each generation varied from five to nine according to infected plants that completed the life cycle and produced seeds. Grow-out tests with seed produced on five plants coinfected with TYMV and TMV were conducted as described.

Location of TYMV and TMV in seed produced on infected plants. To investigate the location of virus in seed, the embryo was separated from the seed coat under a dissecting microscope following a procedure modified from Meinke (29). Dried mature seeds produced by ecotypes Dijon and La-O infected with TYMV or TMV, as well as seeds produced by ecotype La-O coinfected with both TYMV and TMV, were soaked in distilled water for $24 \mathrm{~h}$, as described for the germination assay, to soften the seed coat. Following a slight pressure on the seed with a pair of forceps, the embryo extruded through a crack on the coat. Embryo and seed coat were subjected to infectivity and serological assays, except for those from coinfected plants which were subjected only to serological assay. For infectivity assays, extract of the macerated seed coats or embryos of seed obtained from TYMV- or TMVinfected plants were mechanically inoculated onto Chinese cabbage and N. tabacum, respectively. Groups of seed produced on healthy or virus-infected plants were used as the negative and positive control, respectively. For PAS-ELISA of bulk seed, both the embryo and seed coat were surface disinfected by immersing in a $10 \% \mathrm{Na}_{3} \mathrm{PO}_{4}(\mathrm{wt} / \mathrm{vol})$ solution for $1 \mathrm{~min}$ and then washed three times with distilled water. For detection of TYMV, a single

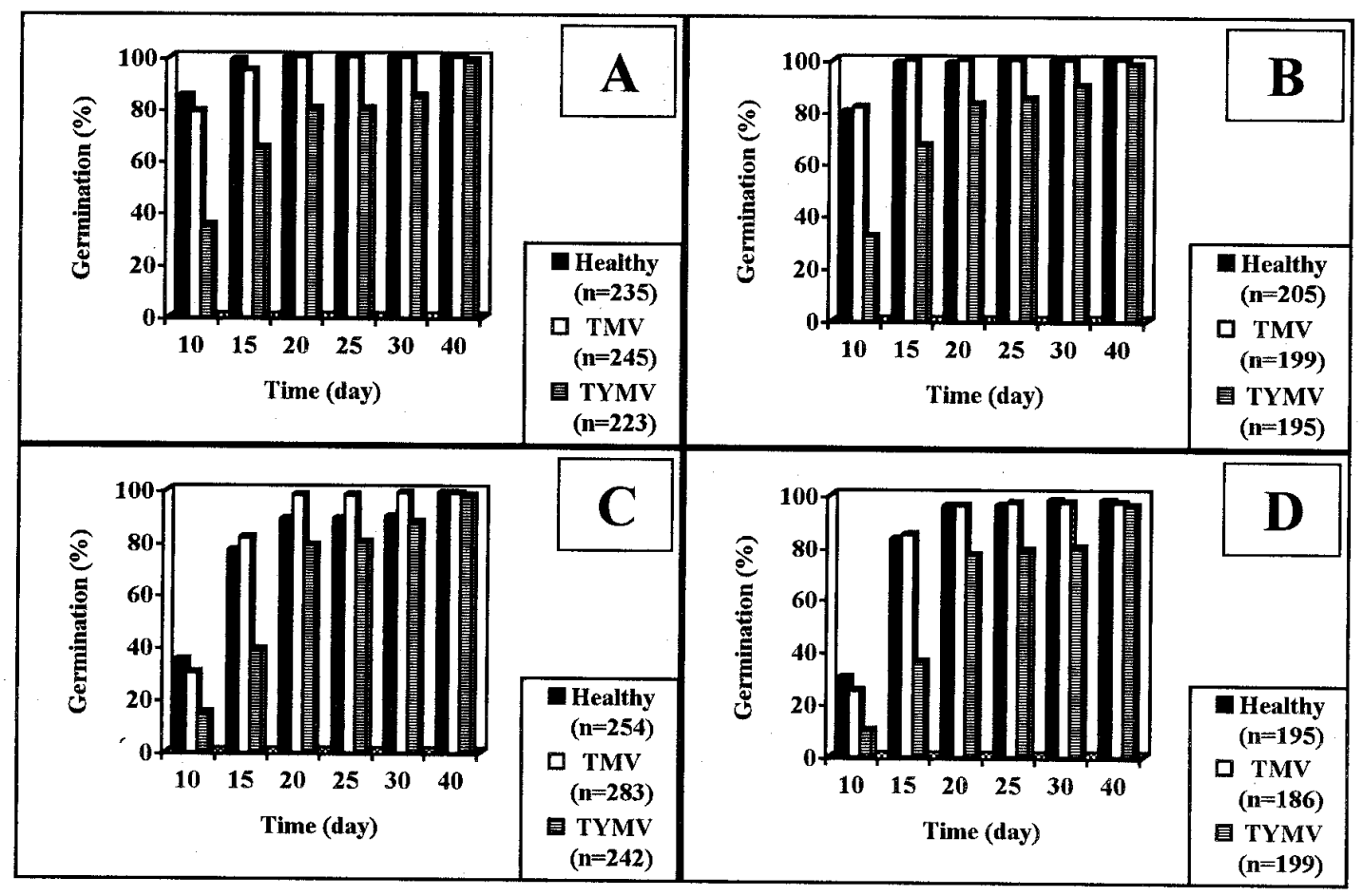

Fig. 1. Effect of Turnip yellow mosaic virus (TYMV) and Tobacco mosaic virus (TMV) on germination of Arabidopsis thaliana seed A and B, Ecotype Dijon and $\mathbf{C}$ and $\mathbf{D}$, Ecotype La-O. Number of seeds in each experiment indicated in legend box. 
seed or seed part was homogenized in $50 \mu$ of sample buffer and tested by PAS-ELISA. To detect TMV, groups of 10 or 20 seed or seed parts were homogenized in $50 \mu$ of sample buffer and tested as described above. For PAS-ELISA of washed seed, groups of 100 seeds were placed in microfuge tubes containing PBST or $0.1 \mathrm{~N} \mathrm{HCl}(2 \mu \mathrm{l}$ per seed) and stirred for $30 \mathrm{~min}$ at room temperature. The washing solution was saved, and seed were rinsed three times with PBST or $0.1 \mathrm{~N} \mathrm{HCl}$ by vortexing for $20 \mathrm{~s}$ and letting the seeds settle for $40 \mathrm{~s}$ to facilitate discarding of the supernatant. Both washing solution and washed seed macerated in PBST were tested by PAS-ELISA.

The route of TYMV and TMV to A. thaliana seed. Crosses between healthy and virus-infected $A$. thaliana plants were carried out by emasculating flowers of the female parent before bud opening in the flower development stages 10 to 11 (40). All flowers subsequently produced were removed to avoid undesirable crosses. Emasculation was done by removing sepals, petals, and stamens with a fine forceps. Each gynoecium was pollinated manually for five consecutive days after emasculation by rubbing the stigma with anthers originating from a male parent. Crosses were made with pollen from a healthy male parent to the gynoecium from an infected female parent and vice versa with 10 female parents for each cross. Some virus-infected plants were allowed to self-pollinate for seed production. Seed was harvested and stored and 3 to 5 weeks later was sown as described previously. All progeny were individually assayed for virus infection by PAS-ELISA at flowering, and the percentages of infected progeny in each treatment were compared.

For evaluation of pollen transmission, leaf, flower, seed, and silique shell from the healthy maternal parent fertilized by pollen from the infected paternal parent was assayed by PAS-ELISA. The assay was done 1 week after pollination and repeated three times at an interval of 1 week.

\section{RESULTS}

Virus distribution in infected plants. The most common visible symptoms in A. thaliana infected with TYMV were mosaic, stunting, delayed flowering, flower abortion, and reduction in size of leaves, flower, and fruits. Symptoms on ecotype Dijon were milder than on ecotype La-O. The symptom of TMV infection was flower abortion. Both TYMV and TMV were detected by PAS-ELISA in all plant tissues of $A$. thaliana ecotypes Dijon and La-O (blossoms, sepals, petals, gynoceium, stamens, siliques, seeds, root, and stem), and virus presence was confirmed by induction of typical symptoms on Chinese cabbage and N. tabacum inoculated with extract of each organ (data not shown). No difference in distribution of TYMV was observed in plants infected either by seed transmission or by mechanical inoculation.

Effect of virus infection on seed germination. The percentage of seeds that germinated from TYMV- and TMV-infected plants was scored over 40 days. The percentage of seeds that germinated

TABLE 1. Determination of percent seed transmission of Turnip yellow mosaic virus through successive generations of Arabidopsis thaliana by grow-out tests ${ }^{\mathrm{z}}$

\begin{tabular}{lcccr}
\hline Ecotype & $\mathrm{SV}_{0}$ & $\mathrm{SV}_{1}$ & \multicolumn{1}{c}{$\mathrm{SV}_{2}$} & \multicolumn{1}{c}{$\mathrm{SV}_{3}$} \\
\hline Dijon & $1.81(778) \mathrm{aA}$ & $7.29(924) \mathrm{bA}$ & $2.58(1,165) \mathrm{aA}$ & $3.07(848) \mathrm{aA}$ \\
La-O & $6.78(445) \mathrm{aB}$ & $27.75(1,003) \mathrm{bB}$ & $23.86(1,109) \mathrm{bcB}$ & $19.96(881) \mathrm{cB}$ \\
\hline
\end{tabular}

${ }^{\mathrm{z}}$ Results are the average of two experiments. A total of 3,715 seedlings of ecotype Dijon and 3,438 seedlings of ecotype La-O were assayed. Numbers in parentheses represent seedlings tested in each generation. Means within a row with the same lower case letter are not significantly different. Means within a column with the same capital letter are not significantly different according to Fisher's exact test $(P=0.05)$ using the SAS System (SAS Institute Inc., Cary, $\mathrm{NC}$ ). $\mathrm{SV}_{0}=$ seeds produced by mechanically infected plants; $\mathrm{SV}_{\mathrm{n}}=$ seeds produced by the $n$-generation of plants grown from infected seed lot. from TMV-infected plants was similar to the percentage of seeds that germinated from healthy plants for both ecotypes. There was a delay in germination of seed from TYMV-infected plants of both ecotypes, but by 40 days the percentage of seeds that germinated from TYMV-infected plants versus the uninfected controls was similar (Fig. 1).Virus antigen was detected in 10 of 15 seeds by PAS-ELISA of single-ungerminated seed from TYMV-infected plants (three of six of ecotype Dijon and seven of nine of ecotype La-O). When individual seed was assayed for TMV by PASELISA no difference in absorbance of seed samples from healthy and TMV-infected plants was observed indicating that the assay was not sensitive enough for antigen detection in single seed.

Evaluation of two methods for determining seed transmission of TYMV and TMV in A. thaliana. In grow-out tests, TYMV was detected in 877 of 7,153 seedlings that originated from seeds produced on TYMV-infected plants (Table 1). TMV was not detected in the 1,606 seedlings tested that were produced from seed obtained from TMV-infected plants. In seed from TYMV-TMV coinfected plants, only TYMV was seed-transmitted (Table 2). The frequency of seed transmission was overestimated by ELISA on the whole seed compared with grow-out tests (Table 3). Hence, ELISA was not an accurate assay to quantify seed transmission of TYMV in A. thaliana.

Location of TYMV and TMV in seeds produced on infected plants. The location and incidence of virus and virus antigen in seed was determined by infectivity and serological assays. Seed for this experiment was obtained from A. thaliana ecotypes Dijon and $\mathrm{La}-\mathrm{O}$ that had been mechanically inoculated. Inoculation onto Chinese cabbage of macerated seed coat or embryo from seeds produced on TYMV-infected plants induced mosaic symptoms typical of TYMV infection. No TMV infection was observed in $N$. tabacum inoculated with either preparation of seed coat or embryo from seeds produced on TMV-infected plants. Inoculum composed of whole seed from TMV-infected plants gave necrotic lesions typical of TMV infection, assuring occurrence of infectious virus, despite the absence of infection of $N$. tabacum inoculated with extract of seed coat only. This may indicate the presence of virus inhibitors in the seed coat of $A$. thaliana that are not effective when inoculum is prepared from whole seed. No infection was recorded from inoculum of whole seed from healthy plants. TYMV antigen was detected in a single seed or part of a single seed, whereas 10 seeds or seed parts of 10 seeds were needed to detect TMV by PAS-ELISA (Table 3).

TABLE 2. Incidence (\%) of Turnip yellow mosaic virus (TYMV) in the embryo, seed coat, or both embryo and seed coat of dissected seed, and in seedlings from Arabidopsis thaliana ecotype La-O singly infected with TYMV or doubly infected with TYMV and Tobacco mosaic virus (TMV) ${ }^{\mathrm{w}}$

\begin{tabular}{lcccc}
\hline Treatment & Embryo & Seed coat & Seed coat and embryo & Seedling \\
\hline TYMV & 0 & 33.3 & 58.9 & $31.1^{\mathrm{x}}$ \\
TYMV + TMV & 1.1 & 22.2 & 75.5 & $70.1^{\mathrm{z}}$ \\
\hline
\end{tabular}

${ }^{\mathrm{w}}$ There was no significant difference in TYMV incidence in (i) embryo only, (ii) seed coat only, and (iii) both seed coat and embryo between treatments. A significant difference was observed in virus incidence in seedlings according to Fisher's exact test $(P=0.05)$. Average of three replications of 30 seeds each. Seeds were dissected into seed coat and embryo. Each part was assayed side by side in the enzyme-linked immunosorbent assay (ELISA) plate to assure the correspondence between them. The occurrence of virus antigen in each seed is represented by three possibilities for TYMV location in seed (columns): embryo invasion but not seed coat invasion; seed coat invasion but not embryo invasion; and seed in which TYMV antigen could be recovered from both the embryo and the seed coat simultaneously.

x Average of two replications of 113 (43.4\%) and 107 (18.7\%) seedlings each determined by grow-out tests.

y Occurrence of TYMV and TMV was confirmed by ELISA with extract of 20 seeds.

${ }^{\mathrm{z}}$ Average of two replications of 108 (70.4\%) and $142(69.7 \%)$ seedlings each determined by grow-out tests. No TMV was detected in seedlings grown from seeds of plants doubly infected with TYMV and TMV. 
These results showed that in both ecotypes TYMV was located either in the embryo or seed coat, but in ecotype Dijon TYMV was detected predominantly in the seed coat. As indicated above, TMV was present in the seed coat but not in the embryo (Table 3). ELISA conducted on seed washed in PBST or $0.1 \mathrm{~N} \mathrm{HCl}$ indicated that TYMV and TMV were present in both washed seeds and the washing solution from their respective samples (data not shown). Although both viruses could be detected in the PBST or $0.1 \mathrm{~N} \mathrm{HCl}$ used to wash the seeds, the amount of antigen in the washed seeds did not appear significantly altered, because ELISA readings of washed and unwashed seed samples were similar, suggesting that TYMV and TMV are predominantly located inside the seed (data not shown).

The route of TYMV and TMV to $A$. thaliana seed. The incidence of TYMV and TMV in the progeny of the crosses between healthy and infected parents was determined by grow-out tests and ELISA. The results indicated that TYMV-infected progeny were obtained from crosses in which either parent was infected with TYMV as well as from self-infected plants (Table 4). The highest incidence of TYMV was observed in seedlings in which both parents were infected. However, when the female parent was infected the incidence of infected progeny was much higher than when the male parent was infected. These results indicate that TYMV can be derived from both the female and male parents. Conversely, TMV was not detected in the progeny of either cross, indicating that no seed transmission had occurred (data not shown). TMV was detected by ELISA in the seed produced from the cross involving an TMV-infected female or when both parents were infected with TMV (Table 5). The absence of TMV in the embryo, implied by the lack of seed transmission, coupled with the presence of virus in the seed coat (Table 3 ) indicated that seed infection by TMV resulted from virus invasion of maternal tissue without embryo involvement.

The vegetative, reproductive, and seed tissues of female parent plants were assayed by PAS-ELISA to better understand the route

TABLE 3. Incidence (\%) of Turnip yellow mosaic virus (TYMV) and Tobacco mosaic virus (TMV) antigens in embryo, seed coat, or both embryo and seed coat in dissected seed, in whole seed, and in seedlings of Arabidopsis thaliana as determined by protein A sandwich enzyme-linked immunosorbent assay ${ }^{\mathrm{x}}$

\begin{tabular}{lccccc}
\hline Treatment & $\begin{array}{c}\text { Embryo } \\
\text { only }\end{array}$ & $\begin{array}{c}\text { Seed coat } \\
\text { only }\end{array}$ & $\begin{array}{c}\text { Seed coat } \\
\text { and embryo }\end{array}$ & Whole seed & Seedlingy \\
\hline Dijon TYMV & $5.4(184)$ & $58.2(184)$ & $10.9(184)$ & $72.6(274)$ & $2.6(423)$ \\
La-O TYMV & $24.5(184)$ & $12.6(184)$ & $13.0(184)$ & $59.5(274)$ & $20.6(471)$ \\
Dijon TMV & $0(180)^{\mathrm{z}}$ & $100(180)^{\mathrm{z}}$ & $0(180)^{\mathrm{z}}$ & $100(180)^{\mathrm{z}}$ & $0(846)$ \\
La-O TMV & $0(180)$ & $100(180)$ & $0(180)$ & $100(180)$ & $0(760)$ \\
\hline
\end{tabular}

$x$ There was a significant difference between TYMV antigen incidence in the embryo and in seedling for both ecotype Dijon and La-O according to Fisher's exact test $(P=0.05)$. Number of seeds individually tested in parentheses.

y Seedling infection determined by grow-out tests.

${ }^{\mathrm{z}}$ Sixty seeds tested as groups of 10 , and 120 as groups of 20 seeds.

TABLE 4. Determination of gamete transmission of Turnip yellow mosaic virus in Arabidopsis thaliana ecotype La-O by protein A sandwich enzymelinked immunosorbent assay (PAS-ELISA) ${ }^{\mathrm{x}}$

\begin{tabular}{lcc}
\hline Cross $^{\mathrm{y}}$ & Total seedlings & Incidence $(\%)^{\mathrm{z}}$ \\
\hline Infected female $\times$ infected male & 390 & $32.31 \mathrm{a}$ \\
Infected female $\times$ healthy male & 466 & $27.25 \mathrm{a}$ \\
Healthy female $\times$ infected male & 468 & $2.14 \mathrm{~b}$ \\
\hline
\end{tabular}

${ }^{x}$ All $F_{1}$ seeds produced by 10 female parents were harvested together. A portion of them was sown in growing medium, and seedlings were maintained in a growth chamber. At flowering, seedlings were individually sampled and tested for virus incidence by ELISA.

y Crosses carried out by emasculation of flower from female parent and hand pollinated by rubbing anther from male parent. Infected female $\times$ infected male was self-pollinated.

${ }^{\mathrm{z}}$ Means with the same letter are not significantly different according to Fisher's exact test $(P=0.05)$. through which TYMV and TMV invade $A$. thaliana seed. TYMV, but not TMV, was present in the flower and seed from the healthy female parent fertilized by pollen from an infected plant (Table 5), indicating that TYMV was carried by pollen into these organs. However, there was no TYMV or TMV invasion of leaves or silique shells (Table 5) indicating infection of the healthy female parent beyond the ovule had not occurred. Detection of TYMV in the flower and in the seed but not in the leaves or in the silique shell, which are of maternal origin, indicates that once TYMV is indirectly introduced into the ovule by infected pollen the virus does not further invade the maternal tissue.

\section{DISCUSSION}

The location of virus in seed determined the transmissibility of virus through seed. TYMV was detected in the embryo and the seed coat of mature seed, whereas TMV was detected only in the seed coat (Table 3). Thus, seed transmissibility is linked to embryo invasion, as others have demonstrated $(4,7,33,46)$. Double infection of $A$. thaliana with TYMV and TMV resulted in a higher percentage of TYMV seed transmission and embryo invasion by TYMV. However, no correlation between seed transmission and embryo invasion was observed (Table 2), suggesting a dosedependent effect in which double infection promoted a higher TYMV titer in the embryo tissue and enhanced seed transmission. An increase of $57 \%$ of Southern bean mosaic virus transmission in seed from cowpea doubly infected with Cowpea chlorotic mottle virus compared with singly infected plants have been reported by Kuhn and Dawson (25).

Except for infection of the embryo, both viruses were similarly distributed in vegetative and reproductive parts of both $A$. thaliana ecotypes. Detection of virus in the reproductive parts, such as the seed coat and silique shell was not surprising because these parts are of maternal origin (29). This is the first report of TYMV transmission in seed of $A$. thaliana, whereas failure of TMV transmission in seed of $A$. thaliana was reported by Ishikawa et al. (22). Seed transmission of TYMV has been reported on Camelina sativa (20), Brassica napus, and Alliama petiolata (41).

The incidence of TYMV seed transmission was higher in ecotype La-O than in Dijon (Table 1). Plant factors may affect the rate of seed transmission in ecotype Dijon, which showed milder infection symptoms and TYMV location predominantly in the seed coat (Table 3). Variation in the incidence of seed transmission among genotypes also has been reported for several virushost combinations $(4,7,9,13,16,21,34,39,43,44,47)$. Over the generations, no pattern was observed within ecotypes. In ecotype Dijon there was significant difference only in the $\mathrm{SV}_{1}$ generation. In ecotype La-O there was a significant increasing of seed transmission in all generations following $\mathrm{SV}_{0}$.

TABLE 5. Detection of Turnip yellow mosaic virus (TYMV) and Tobacco mosaic virus (TMV) in tissue of female parents or seed derived from female parents of crosses of Arabidopsis thaliana ecotype $\mathrm{La}^{\mathrm{O}} \mathrm{O}^{\mathrm{y}}$

\begin{tabular}{|c|c|c|c|c|c|c|}
\hline \multirow[b]{2}{*}{ Organ } & \multicolumn{2}{|c|}{$\mathrm{IF} \times \mathrm{IM}$} & \multicolumn{2}{|c|}{$\mathrm{IF} \times \mathrm{HM}$} & \multicolumn{2}{|c|}{$\mathrm{HF} \times \mathrm{IM}$} \\
\hline & TYMV & TMV & TYMV & TMV & TYMV & TMV \\
\hline Leaf & + & + & + & + & - & - \\
\hline Flower & + & + & + & + & + & - \\
\hline Seed & + & + & + & + & + & - \\
\hline Silique shell ${ }^{\mathrm{z}}$ & + & + & + & + & - & - \\
\hline
\end{tabular}

${ }^{y}$ Healthy females fertilized by pollen from infected male parent were assayed by enzyme-linked immunosorbent assay 1 week after pollination and assayed three additional times at consecutive 1-week intervals, except for seed and silique shell which were assayed at maturity. Flower from $\mathrm{HF} \times$ IM tested positive at 1 week after pollination. Assay was not repeated for flower because it turned to fruit. Crosses conducted by emasculating flower of the female parent and hand pollinating with pollen from the male parent. $\mathrm{IF} \times \mathrm{IM}$ was self-pollinated. $\mathrm{H}=$ healthy; $\mathrm{I}=$ infected; $\mathrm{F}=$ female; $\mathrm{M}=$ male.

z Seed excluded 
The incidence of TYMV antigen in seed was significantly higher than the incidence of seed transmission of TYMV as determined by the grow-out tests (Table 3). Evaluation of the effect of virus infection on seed germination indicated that the results from grow-out tests are not biased due to effects of virus on seed germination, as shown by the frequency of TYMV detection by ELISA in ungerminated seeds (10 of 15), which is close to the frequency of virus in whole seed determined by PAS-ELISA (Table 3). Additional support for this conclusion is provided by the observation that $A$. thaliana usually shows a frequency of spontaneous seed abortion over $0.5 \%$ depending on the growth conditions (29).

The detection of virus antigen in seed may not always be a useful indicator of seed transmission. For the TYMV $\times$ Arabidopsis combination, the ideal condition for ELISA for indexing seed for virus transmission, where the virus is uniformly distributed and highly concentrated in the embryo with no seed coat infection, was not observed. Thus, ELISA should be used with caution in indexing seed for virus transmission. Assay of the progeny generally is the more accurate method of determining virus seed transmission because it overcomes the possible effect of noninfectious virus antigen in seed, as well as, the presence of infectious virus whose location or titer does not lead to seedling infection.

The results presented here show that embryo infection did not assure seedling infection, because the occurrence of TYMV antigen in embryo exceeded the incidence of seed transmission (Table 3). Hampton and Francki (19) observed that virus occurrence in the embryo may exceed the occurrence of seed transmission in several virus-host systems. Similar results were obtained by Wang et al. (47), where overestimation of Pea seedborne mosaic virus transmission was observed by ELISA by either 30-day old embryonic shoots or whole seed compared with grow-out tests. They also observed that healthy seedlings grew from infected embryos. The absence of seedling infection when virus is present in the seed could be due to virus that is not infectious, the titer of the virus being too low, the virus in a location that hampers further infection, or the activities in the cell mitigating successful virus infection $(3,35,44)$. Thus, embryo invasion is necessary, but not always sufficient to lead to seed transmission.

The mechanism resulting in A. thaliana embryo invasion by TYMV but not by TMV is unknown. Studies have shown that viruses can use both a direct and indirect route to infect the embryo $(8,10,21,46)$. The route of TYMV and TMV to the developing seed of A. thaliana was investigated to relate virus movement to the incidence of seed transmission. Through crosses between healthy and virus-infected plants it was demonstrated that TYMV, but not TMV, was carried by pollen into the ovule. TYMV carried by pollen led to infection of flower and seed tissues, whereas maternal vegetative tissue remained virus-free (Table 5). Pollen transmission has not been reported for either TYMV or TMV (30). Seed infection via pollen while the mother plant remains virus-free has been reported for several virus $\times$ host combinations $(5,23,37)$.

The absence of movement of TYMV from the infected embryo to the maternal tissue when infection occurs by pollen supports that the symplastic isolation of TYMV in the embryonic tissue (26) is why virus movement from maternal tissue to the embryo and vice versa is impaired, although it could be due to the physical separation of the tissues as influenced by the sink-source relationship of the developing embryo and maternal tissue. Whereas TYMV could be detected in seeds from healthy female plants fertilized by pollen from virus-infected male plants, the maternally derived silique shell (seed excluded), as well as the leaf tissue remained virus-free (Table 5), indicating the involvement of the male gamete in embryo invasion rather than direct invasion from maternal tissue. The route of TYMV in the female parent leading to seed transmission is far more effective than the route involving the male counterpart as indicated by the higher incidence of infected seedlings from crossing involving the infected female parent (Table 4).
The results presented here show the occurrence of indirect (male gamete) invasion of $A$. thaliana embryo by TYMV, as evidenced by virus occurrence in seed produced by crossing a healthy female with an infected male plant, where only infected pollen can introduce TYMV into the embryo through the sperm cells. On the other hand, TYMV infected the A. thaliana embryo either via the female gamete, by direct invasion from maternal tissue, or by both as indicated by crossing infected female and healthy male plants. The data presented here involving infected female plants do not distinguish between direct and indirect embryo invasion by TYMV.

It was demonstrated that TMV occurs in the seed and in the silique shell, tissue of maternal origin, when the infected female is crossed with either a healthy or a TMV-infected male. However, TMV was not detected in tissue of maternal origin when the healthy female was crossed with a TMV-infected male (Table 5). The absence of TMV in vegetative, reproductive, and seed tissues of $A$. thaliana when a healthy female parent is fertilized by pollen from a TMV-infected male indicates either TMV does not infect the pollen, TMV-infected pollen is less viable, virus-infected pollen does not reach the embryo, or there is a selective barrier to virus infection. Such a selective barrier may exist in A. thaliana, because TYMV was detected by ELISA in the embryo of $A$. thaliana doubly infected by TYMV and TMV (Table 2). Hence, both viruses were detected simultaneously by ELISA in whole seed, yet only TYMV was seed-transmitted. TMV reaches the seed coat but remains apart from the symplastically isolated ovule (embryo sac) and embryo, blocking seed transmission because embryo infection is essential for seed transmission in this system, as it is in most plant $\times$ virus combinations $(1,2,4,12,18,30,33,45)$.

This study indicates that embryo invasion by the virus is necessary but not sufficient to lead to seed transmission. The increase in transmission of TYMV through seed produced on plants coinfected with TYMV and TMV was linked to the increase in the number of embryos invaded by TYMV. TMV is not seed-transmitted in A. thaliana because virus does not invade the embryo. TYMV was carried in pollen and could result in TYMV-infected seed, but virus infection was limited to the developing seed, and systemic infection of the mother plant did not occur typical of pollen transmission of the Ilarvirus and the Nepovirus (28). The model described here could be useful for further studies on the mechanisms that facilitate seed transmission of plant viruses.

\section{ACKNOWLEDGMENTS}

We thank Universidade Federal Rural de Pernambuco (UFRPE) and Conselho Nacional de Desenvolvimento Cientifico e Tecnologico (CNPq), Brazil, for the financial support provided to F. M. de Assis Filho and the Arabidopsis Biological Resource Center for providing Arabidopsis seeds. We thank L. D. Myers for technical support, B. Ding, R. Malmberg, D. W. Meinke, H. A. Melouk, and T. Nickle for helpful advice, M. E. Payton and K. L. Stevenson for statistical analysis, and C. M. Deom and R. Naidu for critical review of the manuscript.

\section{LITERATURE CITED}

1. Adams, D. B., and Kuhn, C. W. 1977. Seed transmission of peanut mottle virus in peanuts. Phytopathology 67:1126-1129.

2. Agarwal, V. K., and Sinclair, J. B. 1996. Principles of Seed Pathology. 2nd ed. Lewis Publishers, Boca Raton, FL.

3. Alvarez, M., and Campbell, R. N. 1978. Transmission and distribution of squash mosaic virus in seed of cantaloupe. Phytopathology 68:257-263.

4. Bailiss, K. W., and Offei, S. K. 1990. Alfalfa mosaic virus in lucerne seed during seed maturation and storage, and in seedlings. Plant Pathol. 39:539-547.

5. Bennett, C. W. 1969. Seed transmission of plant viruses. Adv. Virus Res. 14:221-261.

6. Bharathan, N., Reddy, D. V. R., Rajeshwary, R., Muphy, V. K., and Rao, V. R. 1984. Screening peanut germ plasm lines by enzyme-linked immunosorbent assay for seed transmission of peanut mottle virus. Plant Dis. 68:757-758.

7. Bowers, G. R., Jr., and Goodman, R. M. 1979. Soybean mosaic virus: 
Infection of soybean seed parts and seed transmission. Phytopathology 69:569-572.

8. Carroll, T. W. 1972. Seed transmissibility of two strains of barley stripe mosaic virus. Virology 48:323-336.

9. Carroll, T. W., and Chapman, S. R. 1970. Variation in embryo infection and seed transmission of barley stripe mosaic virus within and between two cultivars of barley. Phytopathology 60:1079-1081.

10. Carroll, T. W., and Mayhew, D. E. 1976. Anther and pollen infection in relation to the pollen and seed transmissibility of two strains of barley stripe mosaic virus in barley. Can. J. Bot. 54:1604-1621.

11. Clark, M. F. 1981. Immunosorbent assays in plant pathology. Ann. Rev. Phytopathol. 19:83-106.

12. Crowley, N. C. 1957. Studies on the seed transmission of plant virus diseases. Aust. J. Biol. Sci. 10:449-464.

13. Culver, J. N., and Sherwood, J. L. 1988. Detection of peanut stripe mosaic virus in peanut seed by an indirect enzyme-linked immunosorbent assay using a monoclonal antibody. Plant Dis. 72:676-679.

14. Edwards, M. L., and Cooper, J. I. 1985. Plant virus detection using a new form of indirect ELISA. J. Virol. Methods 11:309-319.

15. Falk, B. W., and Purcifull, D. E. 1983. Development and application of an enzyme-linked immunosorbent assay (ELISA) test to index lettuce seeds for lettuce mosaic virus in Florida. Plant Dis. 67:413-416.

16. Ghanekar, A. M., and Schuwenk, F. W. 1974. Seed transmission and distribution of tobacco streak virus in six cultivars of soybeans. Phytopathology 64:112-114.

17. Gillaspie, A. G., Jr., Hopkins, M. S., and Pinnow, D. L. 1993. Relationship of cowpea seed part infection and seed transmission of blackeye cowpea mosaic potyvirus in cowpea. Plant Dis. 77:875-877.

18. Gupta, M. D., and Summanwal, A. S. 1980. The location of two mosaic viruses in cowpea seeds. Seed Sci. Technol. 8:203-206.

19. Hampton, R. O., and Francki, R. I. B. 1992. RNA 1 dependent seed transmissibility of cucumber mosaic virus in Phaseolus vulgaris. Phytopathology 82:127-130.

20. Hein, A. 1984. Transmission of turnip yellow mosaic virus through seed of Camelina sativa (gold of pleasure). J. Plant Dis. Prot. 91:549-551.

21. Hemmati, K., and McLean, D. L. 1977. Gamete-seed transmission of alfalfa mosaic virus and its effect on seed germination and yield in alfalfa plants. Phytopathology 67:576-579.

22. Ishikawa, M., Obata, F., Kumagai, T., and Ohino, T. 1991. Isolation of mutants of Arabidopsis thaliana in which accumulation of tobacco mosaic tobamovirus coat protein is reduced to low levels. Mol. Gen. Genet. 230:33-38.

23. Johansen, E., Edwards, M. C., and Hampton, R. O. 1994. Seed transmission of viruses: Current perspectives. Ann. Rev. Phytopathol. 32:363-386.

24. Jones, A. T. 1993. Experimental transmission of viruses in diagnosis. Pages 49-72 in: Diagnosis of Plant Virus Diseases. R. E. F. Matthews, ed. CRC Press, Boca Raton, FL.

25. Kuhn, C. W., and Dawson, W. O. 1973. Southern bean mosaic virus in single and double infections in cowpea. Phytopathology 63:1380-1385.

26. Mansfield, S. G., and Briarty, L. G. 1991. Early embryogenesis in Arabidopsis thaliana. II. The developing embryo. Can. J. Bot. 69:461-476.

27. Matthews, R. E. F. 1980. Turnip yellow mosaic virus. No. 230 in: Plant Viruses. Commonw. Mycol. Inst./Assoc. Appl. Biol., Kew, England.

28. Maury, Y., Duby, C., and Khetarpal, R. K. 1998. Seed certification for viruses. Pages 237-248 in: Plant Virus Disease Control. A. Hadidi, R. K. Khetarpal, and H. Koganezawa, eds. The American Phytopathological
Society, St. Paul, MN

29. Meinke, D. W. 1994. Seed Development in Arabidopsis thaliana. Pages 253-295 in: Arabidospsis. E. M. Meyerowitz and C. R. Somerville, eds. Cold Spring Harbor Laboratory, Cold Spring Harbor, NY.

30. Mink, G. I. 1993. Pollen- and seed-transmitted viruses and viroids. Ann. Rev. Phytopathol. 31:375-402.

31. Neegaard, P. 1979. Seed Pathology. Vol. 1. McMillan Press, London.

32. Nolan, P.A., and Campbell, R. N. 1984. Squash mosaic virus detection in individual seeds and seed lots of cucurbits by enzyme-linked immunosorbent assay. Plant Dis. 68:971-975.

33. Pesic, Z., and Hiruki, C. 1986. Differences in the incidence of alfalfa mosaic virus in seed coat and embryo of alfalfa seed. Can. J. Plant Pathol. 8:39-42.

34. Porto, M. D. M., and Hagedorn, D. J. 1975. Seed transmission of a Brazilian isolate of soybean mosaic virus. Phytopathology 65:713-716.

35. Powell, C. C., Jr., and Schlegel, D. E. 1970. The histological localization of squash mosaic virus in cantaloupe seedlings. Virology 42:123-127.

36. Rezende, J. A. M., Urban, L., Sherwood, J. L., and Melcher, U. 1992. Host effect on cross protection between two strains of tobacco mosaic virus. J. Phytopathol. 136:147-153.

37. Sdoodee, R., and Teakle, D. S. 1988. Seed and pollen transmission of tobacco streak virus in tomato (Lycopersicon esculentum cv. Grosse Lisse). Aust. J. Agric. Res. 39:469-474.

38. Sherwood, J. L., and Fulton, R. W. 1982. The specific involvement of coat protein in tobacco mosaic virus cross protection. Virology 119: 150-158.

39. Smith, F. L., and Hewitt, W. B. 1938. Varietal susceptibility to common bean mosaic and transmission through seed. Calif. Agric. Exp. Stn. Bull. 621.

40. Smyth, D. R., Bowman, J. L., and Meyerowitz, E. M. 1990. Early flower development in Arabidopsis thaliana. Plant Cell 2:755-767.

41. Spak, J., Kubelkova, D., and Hnilicka, E. 1993. Seed transmission of turnip yellow mosaic virus in winter turnip oilseed rapes. Ann. Appl. Biol. 123:33-35

42. Sutula, C. L., Gillett, J. M., Morrissey, S. M., and Ramsdell, D. C. 1986. Interpreting ELISA data and establishing the positive-negative threshold. Plant Dis. 70:722-726.

43. Tu, J. C. 1992. Symptom severity, yield, seed mottling, and seed transmission of soybean mosaic virus in susceptible and resistant soybean: The influence of infection stage and growth temperature. J. Phytopathol. 135:28-36.

44. Varma, A., Krishnareddy, M., and Malathi, V. G. 1992. Influence of the amount of blackgram mottle virus in different tissues on transmission through the seeds of Vigna mungo. Plant Pathol. 41:274-281.

45. Von Wechmar, M. B., Kaufmann, A., Desmarais, F., and Rybicki, E. P. 1984. Detection of seed-transmitted brome mosaic virus by ELISA, radial immunodiffusion, and immunoelectroblotting tests. J. Phytopathol. 109:341-352.

46. Wang, D., and Maule, A. J. 1994. A model for seed transmission of a plant virus: Genetic and structural analyses of pea embryo invasion by pea seed-borne mosaic virus. Plant Cell 6:777-787.

47. Wang, D., Woods, R. D., Cockbain, A. J., Maule, A. J., and Biddle, A. J. 1993. The susceptibility of pea cultivars to pea seed borne mosaic virus infection and virus seed transmission. Plant Pathol. 42:42-47.

48. Zaitlin, M., and Israel, H. W. 1975. Tobacco mosaic virus (type strain) No. 151 in: Plant Viruses. Commonw. Mycol. Inst./Assoc. Appl. Biol., Kew, England. 